\title{
An attempt to improve nurses' interest in and use of research in clinical practice by means of network support to 'facilitator nurses'
}

\author{
Monica E. Björkström¹, Inger S. Johansson ${ }^{1,2}$, Elsy E. Athlin ${ }^{1}$ \\ 1. Department of Health Sciences, Karlstad University, Karlstad, Sweden. 2. Gjøvik University College, Gjøvik, Norway.
}

Correspondence: Monica Elisabeth Björkström. Address: Department of Health Sciences, Karlstad University, Karlstad, Sweden. Email: monica.bjorkstrom@kau.se

Received: July 2, 2013

DOI : 10.5430/jnep.v4n3p58
Accepted: September 2, 2013

URL: http://dx.doi.org/10.5430/jnep.v4n3p58

\section{Abstract}

Background: Scientific knowledge is expected to be used in clinical practice to ensure that patients are given evidence-based nursing care. Therefore, in order to improve nurses' research utilisation in clinical practice a network had been provided for nurses especially interested in nursing development in eleven wards. These nurses were expected to take on the role of key person (facilitator) for nursing development in clinical practice.

Aim: The study was aimed at describing nurses' interest in nursing research, how network support to 'facilitator nurses' could improve development in patient care based on evidence, and what hindering factors for such development could be.

Methods: One and a half years after onset of the project a follow-up study was conducted with a questionnaire answered by 75 (64\%) nurses, and group interviews with nine facilitators and eleven head nurses.

Findings: The nurses' interest in research utilisation was in general high and in eight wards development work had started. The facilitator nurses had mostly worked without involving their colleagues. Hindering factors for nursing development were related to time, EBP knowledge, involvement and the interest of head nurses and colleagues. Education, work place, previous participation in research projects, and participation in the network impacted positively on nurses' attitudes to and interest in research.

Conclusion and implication for clinical practice: Providing networks to 'facilitator nurses' in the ward could be useful for developing nursing care based on research findings. However, support from nurse leaders, involvement of the whole nursing staff, and training in research utilisation are important factors for success.

\section{Key words}

Clinical nursing, Evidence-based practice, Facilitator, Network support, Research utilisation

\section{I ntroduction}

During recent decades research in the nursing field has expanded rapidly, resulting in a huge body of nursing knowledge. This scientific knowledge is expected to be used in clinical practice to ensure that patients are provided evidence-based nursing care ${ }^{[1-3]}$. However, there is a great amount of literature reporting that this new research-based knowledge seldom reaches nurses in clinical work ${ }^{[4,5]}$. Different reasons of individual and organisational nature have been reported, such as 
lack of time, lack of interest or knowledge among the nursing personnel, lack of authority and organisational support ${ }^{[6-8]}$ hindering workplace culture ${ }^{[9,10]}$, and leadership attitudes ${ }^{[5,11]}$.

Studies highlight that attitudes towards research are heavily influenced by the work environment in the clinical fields ${ }^{[12]}$, and also by the individual nurses' interest and knowledge about research and nursing development ${ }^{[13]}$. Therefore many frameworks and models have been created during recent decades in order to inspire nurses to use research in clinical practice to improve nursing care. The framework proposed by Kitson and co-workers ${ }^{[14,15]}$ has often been referred to. Their framework highlights the necessity of using both a 'bottom- up' and 'top-down' strategy in development of care. The same research group has also emphasized the necessity of collaboration, mutual support, critical challenge, reflexivity and empowerment of individuals in order to make changes ${ }^{[16]}$. The value of collaboration between the nursing academy and the clinical practice of health care has been illuminated by these researchers and others ${ }^{[17,18]}$. As nurse lecturers of today are competent and responsible for teaching about research in theory, they are in a unique position to facilitate evidence-based nursing in health institutions ${ }^{[17]}$.

\section{The project}

In one county in Sweden the university and collaborating health-care institutions where nursing students were trained had over the years strived to find methods for improving research utilisation in clinical practice. One attempt had been to provide a network for clinical nurses especially interested in nursing development. The purpose was to inspire and support these nurses to take on a facilitator role ${ }^{[19,20]}$ for nursing development at the workplace. The network, which was initiated from the university after agreement with head nurses, was led by a senior nurse lecturer and a nurse lecturer, and was offered three times per semester at three hospitals. Two nurses per ward were initially invited to be key persons (facilitators) for nursing development. They were expected to inspire and support their colleagues to start up a development work based on the principles of Evidence-Based Practice (EBP) ${ }^{[21]}$. This meant that together with their colleagues in the ward they were expected to critically review the current practice, identify an improvement area of nursing care, search for evidence for 'best practice' in scientific literature, and apply the evidence to their practice ${ }^{\text {[c.f. } 22]}$. In the network meetings both theoretical and emotional support in the facilitator role were provided.

\section{The study}

This study was carried out one and a half years after the onset of the network with the aim of describing nurses' interest in nursing research, how network support to 'facilitator nurses' could improve development in patient care based on evidence, and what hindering factors for such development could be.

\section{Methods}

\subsection{Subjects and data collection}

The study was carried out at one urban and two rural hospitals in central Sweden where the network support had been going on for 1.5 years. Eleven wards, specializing in paediatric, medical, surgical and emergency care, were included. A questionnaire based on statements designed by Björkström and Hamrin ${ }^{[23]}$ was used to investigate the nurses' attitudes to and interests in research and development in the area of nursing. The questionnaire was comprised of three parts: 1) demographic data of the respondents; 2) thirty-five Likert-type statements about attitudes towards nursing research and development; and 3) questions about 'research awareness'. The response alternatives for each of the 35 statements were rated 1-5 as follows: (1) do not agree at all; (2) agree to a little extent; (3) agree to a certain extent; (4) agree to a great extent; and (5) agree to a very great extent. In the original study ${ }^{[23]}$ the following seven factors were determined by factor analysis and with Cronbach's alpha values varied between 0.60-0.84: Factor 1 'Research language' (two statements), Factor 2 'Need for research knowledge' (five statements), Factor 3 'Participation' (six statements), Factor 4 'The Profession' (five statements), Factor 5 'Meaningfulness' (five statements), Factor 6 'Study literature' (six statements) 
Factor 7 'Developing - Resources' (five statements). In the present study one statement was removed since it was not included in the factor analysis in the original study ${ }^{[23]}$. The instrument was extended with three questions: participation in the network, ongoing development work and whether development work was initiated by the network with the response alternatives 'yes' or 'no'.

The head nurses in the wards informed their nurses about the study and distributed the questionnaires to them. Out of one hundred and seventeen questionnaires distributed 75 (64\%) were answered and returned after two reminders. In addition, the facilitators and the head nurses were asked to participate in a group interview. All head nurses and nine of eleven facilitators agreed. The interviews were carried out in three groups of facilitators ( $n=9,2-4$ per group) and three groups of head nurses ( $\mathrm{n}=11,3-4$ per group). The interviews were tape-recorded and transcribed verbatim. In this study data were used from two questions - 'the impact of the network on development work' and 'obstacles for development work'.

\subsection{Data analysis}

Data from the questionnaires were analysed using the software Statistical Package for Social Sciences, (SPSS) for Windows version 18. When computing, negative statements were changed to positive, with a score of 1 being counted as 5 and a score of 5 as 1 . The level of significance was set to $p \leq .05$. Descriptive analysis was used for frequencies, groups mean values and standard deviation (SD). The non-parametric methods Mann-Whitney U-Test and Pearson's $\chi^{2}$ test with Fisher's exact test when the expected frequencies were less than five were used for test of significance ${ }^{[24]}$.

Missing data on single statements were replaced by mean value substitution when processing total items and the factors/subscale ${ }^{[25]}$. Missing data on single questions are presented in the text.

The questions from the group interviews were analysed by means of content analysis ${ }^{[25]}$. The transcripts were carefully read through in order to get an overall understanding of the content. Thereafter, words and phrases related to 'the impact of the network on development work' and 'obstacles for development work' were identified as meaningful units, condensed, sorted, and categorized. The analysis was first carried out by one author (MB), followed by a comparison of meaningful units with categories carried out by another one (EA) in order to increase the validity. The categories were finally discussed in the whole research team (MB, IJ, EA) until consensus was reached ${ }^{[26]}$.

\subsection{Ethical considerations}

Permission for the study was obtained from the head of the Department of Nursing and the heads of the wards. The study was conducted in accordance with the Nordic guidelines for nursing research in the Nordic countries ${ }^{[27]}$. Participation was voluntary, confidentiality was guaranteed, and informed consent was obtained.

\section{Findings}

\subsection{Background data}

The nurses' profile shows that most of the respondents were women between 30-49 years, had a nursing education completed before 1996, were working at rural hospitals and had worked six years or more at the current workplace. About half of them were responsible for a specific area in nursing and one quarter had at some time participated in nursing research or development work in nursing (see Table 1). More than two-thirds of the nurses $(n=52)$ had academic studies in nursing after their legislation (not in table). Of them, $14 \%(n=7)$ had further studies towards a Bachelor degree or Master degree in Nursing. Most of the nurses who had previously participated in nursing research or development work in nursing were working at the urban hospital ( $n=12$ of 19,63\%) (not in table). Fifteen percent (11 of 71) of the respondents were facilitators who had participated in the network a few to several times. These facilitators represented seven of the eleven wards included in the study. 
Table 1. The Nurses' Background Data

\begin{tabular}{|c|c|c|c|}
\hline & & \multicolumn{2}{|c|}{ Nurses $n=75$} \\
\hline & & $\mathbf{N}$ & $\%$ \\
\hline \multirow[t]{3}{*}{ Gender } & - female & 72 & 96 \\
\hline & - male & 3 & 4 \\
\hline & -Total & 75 & 100 \\
\hline \multirow[t]{5}{*}{ Age, years } & $-20-29$ & 2 & 3 \\
\hline & $-30-39$ & 26 & 35 \\
\hline & $-40-49$ & 26 & 35 \\
\hline & $-50-$ & 20 & 27 \\
\hline & Total & 74 & 100 \\
\hline \multirow[t]{3}{*}{ Year of completing education } & $\leq 1995$ (Diploma) & 53 & 71 \\
\hline & $\geq 1996$ (Bachelor) & 22 & 29 \\
\hline & Total & 75 & 100 \\
\hline \multirow[t]{3}{*}{ Workplace } & - urban hospital & 28 & 37 \\
\hline & - rural hospital & 47 & 63 \\
\hline & Total & 75 & 100 \\
\hline \multirow{3}{*}{$\begin{array}{l}\text { Responsible for a specific area in } \\
\text { nursing }\end{array}$} & - yes & 34 & 48 \\
\hline & - no & 37 & 52 \\
\hline & Total & 71 & 100 \\
\hline \multirow[t]{5}{*}{ Years at current work place } & $0-1$ & 5 & 7 \\
\hline & $2-5$ & 25 & 33 \\
\hline & $6-9$ & 19 & 25 \\
\hline & $10-$ & 26 & 35 \\
\hline & Total & 75 & 100 \\
\hline \multirow{3}{*}{$\begin{array}{l}\text { Participation in nursing research/ } \\
\text { development projects }\end{array}$} & - yes & 19 & 25 \\
\hline & - no & 56 & 75 \\
\hline & Total & 75 & 100 \\
\hline
\end{tabular}

\subsection{Attitudes towards nursing research}

Most of the respondents had a positive attitude towards nursing research. The finding shows a high total value (sum of all 34 variables) in their answers varying between 74 and 169, and the mean value was 113.4 and SD 21.7. The nurses were more positive (mean score $\geq 3.4$ ) to the factors 'Need of research' (Factor 2), 'The profession' (Factor 4), 'Meaningfulness' (Factor 5) and 'Developing - Resources' (Factor 7) than to the factors 'Research language' (Factor 1), 'Participation' (Factor 3) and 'Study literature' (Factor 6). The less positive statements $(<3)$ were found in Factor 1 'Research language' (statements 9, 21), Factor 3 'Participation' (statements 11, 22, 25, 27), Factor 4 'The Profession' (statement 28) and Factor 6 'Study literature' (statements 4, 13) (see Table 2).

The facilitators who had taken part in the network were in some part significantly more positive towards nursing research than the other staff nurses in the ward. The facilitators had a significantly higher mean value of total items and their attitudes were significantly more positive to 'Need for research knowledge' (Factor 2), 'Participation' (Factor 3), 'The Profession' (Factor 4) and 'Study literature' (Factor 6) than the staff nurses in the wards (see Table 3).

The mean values of the total items, and the values of the factors concerning attitudes towards nursing research showed significant differences in some groups with regard to nurses' background data (see Table 4). Nurses who had completed nursing education in 1996 or later were significantly more positive to 'The profession' (Factor 4), 'Meaningfulness' (Factor 5) and 'Study literature' (Factor 6) than those who had completed their education before 1996. Nurses with higher academic studies in nursing care after legalization (BSC or $M S c$ ) had a significantly higher sum of total items and were overall significantly more positive to all factors except to Factor 7 'Developing - Resources' than nurses with less academic studies (courses). Nurses working at the urban hospital had a significantly higher sum of total items and were 
significantly more positive to all factors than nurses working at rural hospitals. Nurses who had participated in some nursing research/development projects had a significantly higher sum of total items and were significantly more positive to all factors except 'Research language' (Factor 1) and 'Developing - Resources' (Factor 7) than nurses without this experience. No significance was found related to gender, age and responsibility for a specific area in nursing.

Table 2. Nurses' Attitudes towards Nursing Research, Total Items, Factors and Items, Mean Value and Standard Deviation (SD)

\begin{tabular}{|c|c|c|}
\hline Total items*, Factors*, Items & & $\begin{array}{l}\text { Nurses }(\mathbf{n}=75) \\
\text { Mean/SD }\end{array}$ \\
\hline Total items (item value $=34-170)$ & & 113.38/21.68 \\
\hline Factor 1 'Research language’' (sum mean-score/SD = 5.48/1.86) & & 2.7/0.9 \\
\hline 9.The language in scientific articles is too complicated for me $(n=75)$ & - & 2.89/1.11 \\
\hline 21.The language used in nursing research is much too complicated $(n=74)$ & - & $2.58 / 0.99$ \\
\hline Factor 2 ‘Need of research knowledge’ (sum mean-score/SD = 17.98/4.27) & & 3.6/0.9 \\
\hline 3. In the nursing area too much is written and there is too much talk about research and development $(n=75)$ & - & $3.35 / 1.20$ \\
\hline 5. Nurses are not in need of knowledge based on research as much as doctors $(n=75)$ & - & $3.85 / 1.01$ \\
\hline 6. Nursing research describes and makes the nursing work visible $(n=74)$ & + & $3.69 / 0.98$ \\
\hline 12. We do not need any researchers in nursing to develop the care, the nurses will manage that by themselves $(n=74)$ & - & $3.82 / 1.05$ \\
\hline 15. Nursing research complicates the daily nursing work $(n=73)$ & - & $3.26 / 1.13$ \\
\hline Factor 3 'Participation’ (sum mean-score/SD = 18.08/4.73) & & 3.0/0.8 \\
\hline 11. The nurse's duties should include participation in development in the nursing area $(n=75)$ & + & $2.92 / 1.14$ \\
\hline 22. In the practical work there should be more nurses with a $\mathrm{PhD} /$ research education $(n=74)$ & + & $2.84 / 0.95$ \\
\hline 24. Nursing research results should be more widely spread to nurses $(n=75)$ & + & $3.91 / 0.83$ \\
\hline 25. Nursing research is essential to me in my development as a professional nurse $(n=75)$ & + & $2.91 / 0.99$ \\
\hline 27. The nurse's duty should include participation in research $(n=75)$ & + & $2.45 / 1.09$ \\
\hline 35. I think the questions in this questionnaire are important $(n=73)$ & + & $3.04 / 1.03$ \\
\hline Factor 4 ‘The Profession’ (sum mean-score/SD = 16.96/3.48) & & 3.4/0.7 \\
\hline 7. The nursing profession consists of practical work and does not have to include research $(n=75)$ & - & $3.89 / 1.05$ \\
\hline 19. Further education in research and a research connection are not important for the future $(n=72)$ & - & $3.90 / 1.00$ \\
\hline $\begin{array}{l}\text { 20. As a nurse I have enough influence on my nursing work, without having the need for any knowledge about } \\
\text { research }(n=75)\end{array}$ & - & $3.51 / 1.07$ \\
\hline 23. To participate in research does not contribute to increased skills in nursing $(n=74)$ & - & $3.27 / 1.09$ \\
\hline 28. The nurse's professional skills are above all obtained through long experience $(n=75)$ & - & $2.37 / 0.94$ \\
\hline Factor 5 ‘Meaningfulness’ (sum mean-score/SD = 18.46/3.69) & & $3.7 / 0.7$ \\
\hline 2. To participate in development in nursing does not promote professional skills $(n=74)$ & - & $3.62 / 1.07$ \\
\hline 10. There is no point in devoting your time to development in nursing $(n=75)$ & - & $4.07 / 0.95$ \\
\hline 17. Nursing research does not give the nursing profession a higher status $(n=75)$ & - & $3.25 / 1.23$ \\
\hline 26. It is not realistic to apply nursing research to the practical work $(n=73)$ & - & $3.62 / 0.94$ \\
\hline 32. There is no point in devoting one's time to research in nursing $(n=75)$ & - & $3.89 / 0.92$ \\
\hline Factor 6 'Study literature’ (sum mean-score/SD = 18.52/4.90) & & $3.1 / 0.8$ \\
\hline 1. As a nurse you must be able to read literature in English $(n=75)$ & + & $3.05 / 1.15$ \\
\hline 4. I think it is interesting to read scientific articles about nursing care $(n=74)$ & + & 2.95/1.07 \\
\hline 8. At the work place (e.g. the ward) current research literature about nursing care should be available $(n=75)$ & + & $3.52 / 0.94$ \\
\hline 13. I am keen to attend international research conferences $(n=74)$ & + & $2.31 / 1.33$ \\
\hline 29. I do not bother to find out about research results $(n=75)$ & - & $3.32 / 1.12$ \\
\hline 33. Nurses ought to take the time to read research reports $(n=75)$ & + & $3.36 / 0.98$ \\
\hline Factor 7 'Developing - Resources’ (sum mean-score/SD = 17.90/2.95) & & 3.6/0.6 \\
\hline $\begin{array}{l}\text { 16. Lecturers from the nursing education should be a resource for stimulating the development of nursing in the } \\
\text { workplace (e.g. the ward) }(n=75)\end{array}$ & + & $3.43 / 1.04$ \\
\hline $\begin{array}{l}\text { 18. The PhD-degree for nurses should be a necessary qualification for securing some higher positions in the nursing } \\
\text { area }(n=71)\end{array}$ & + & $3.27 / 1.13$ \\
\hline $\begin{array}{l}\text { 30. Nursing students should be a resource for stimulating the development of nursing care in the work place (e.g. the } \\
\text { ward) }(n=74)\end{array}$ & + & $3.14 / 1.00$ \\
\hline 31. It goes without saying that the nursing profession should be built on empirical knowledge and research $(n=75)$ & + & 4.19/0.82 \\
\hline 34. To introduce changes and to try new ideas is very important in the nursing profession $(n=75)$ & + & $3.88 / 0.81$ \\
\hline
\end{tabular}


Table 3. Attitudes towards Nursing Research; Comparison between Facilitators and Staff Nurses $\left(n=71^{*}\right)$

\begin{tabular}{|c|c|c|}
\hline Items/factors & $\begin{array}{l}\text { Facilitators }(n=11) \\
\text { M/SD }\end{array}$ & $\begin{array}{l}\text { Staff nurses }(n=60) \\
\text { M/SD }\end{array}$ \\
\hline Total items (34-170) & $126.99 / 17.33$ & $110.17 / 21.46$ \\
\hline Z-value/P-value & $-2.615 / 0.009$ & \\
\hline 'Research language' (Factor 1) & $5.36 / 2.25$ & $5.50 / 1.86$ \\
\hline Z-value/P-value & $-0,162 / 0.872$ & \\
\hline 'Need of research knowledge' (Factor 2) & $21.00 / 2.83$ & $17.30 / 4.28$ \\
\hline Z-value/P-value & $-2.608 / 0.009$ & \\
\hline 'Participation' (Factor 3) & $20.45 / 3.80$ & $17.51 / 4.66$ \\
\hline Z-value/P-value & $-2.422 / 0.015$ & \\
\hline 'The profession' (Factor 4) & $19.00 / 3.22$ & $16.48 / 3.34$ \\
\hline Z-value/P-value & $-2.429 / 0.015$ & \\
\hline 'Meaningfulness' (Factor 5) & $20.18 / 3.81$ & $18.04 / 3.61$ \\
\hline Z-value/P-value & $-1.850 / 0.064$ & \\
\hline 'Study literature' (Factor 6) & $22.17 / 3.14$ & $17.77 / 4.92$ \\
\hline Z-value/P-value & $-3.053 / 0.002$ & \\
\hline 'Developing - Resources' (Factor 7) & $18.81 / 2.14$ & $17.58 / 3.04$ \\
\hline Z-value/P-value & $-1.669 / 0.095$ & \\
\hline
\end{tabular}

Table 4. The Nurses' Attitudes towards Nursing Research and Significant Differences in Background Data

\begin{tabular}{|c|c|c|c|c|c|c|c|c|}
\hline & \multicolumn{2}{|c|}{$\begin{array}{l}\text { Year of nursing education } \\
\text { completed }(n=75)\end{array}$} & \multicolumn{2}{|c|}{$\begin{array}{l}\text { Further academic studies in } \\
\text { nursing care after nurse } \\
\text { exam }(n=52)\end{array}$} & \multicolumn{2}{|c|}{$\begin{array}{l}\text { Hospital workplace } \\
(n=75)\end{array}$} & \multicolumn{2}{|c|}{$\begin{array}{l}\text { Participation in nursing } \\
\text { research/development } \\
\text { projects }(n=75)\end{array}$} \\
\hline & $\begin{array}{l}\leq 1995 \\
(\mathrm{n}=54) \\
\mathrm{M} / \mathrm{SD}\end{array}$ & $\begin{array}{l}\geq 1996 \\
(n=21) \\
M / S D\end{array}$ & $\begin{array}{l}\text { Courses } \\
(\mathrm{n}=45) \\
\mathrm{M} / \mathrm{SD}\end{array}$ & $\begin{array}{l}\mathrm{BSc} / \mathrm{MSc} \\
(\mathrm{n}=4 / 3) \\
\mathrm{M} / \mathrm{SD}\end{array}$ & $\begin{array}{l}\text { Urban } \\
(\mathrm{n}=28) \\
\mathrm{M} / \mathrm{SD}\end{array}$ & $\begin{array}{l}\text { Rural } \\
(n=47) \\
M / S D\end{array}$ & $\begin{array}{l}\text { Yes } \\
(\mathrm{n}=19) \\
\mathrm{M} / \mathrm{SD}\end{array}$ & $\begin{array}{l}\text { No } \\
(n=56) \\
M / S D\end{array}$ \\
\hline Total items & $110.8 / 22.2$ & $120.1 / 19.0$ & $113.1 / 20.0$ & $140.7 / 20.4$ & $128.5 / 20.6$ & $104.4 / 16.9$ & $126.1 / 18.9$ & $109.1 / 21.0$ \\
\hline Z-/P-value & $-1.900 / 0.057$ & & $-2.722 / 0.005$ & & $-4.678 / 0.000$ & & $-3.223 / 0.001$ & \\
\hline $\begin{array}{l}\text { 'Research language' } \\
\text { (Factor 1) }\end{array}$ & $5.38 / 1.92$ & $5.71 / 1.71$ & $5.22 / 1.70$ & $7.71 / 1.50$ & $6.13 / 1.60$ & $5.08 / 1.91$ & $6.14 / 1.92$ & $5.25 / 1.80$ \\
\hline Z-/P-value & $-0.925 / 0.355$ & & $-3.110 / 0.001$ & & $-2.264 / 0.024$ & & $-1.724 / 0.085$ & \\
\hline $\begin{array}{l}\text { 'Need of research } \\
\text { knowledge' (Factor 2) }\end{array}$ & $17.49 / 4.32$ & $19.24 / 3.97$ & $18.01 / 4.24$ & $21.71 / 3.20$ & $20.79 / 4.28$ & $16.32 / 3.32$ & $20.45 / 3.90$ & $17.15 / 4.10$ \\
\hline Z-/P-value & $-1.747 / 0.081$ & & $-2.139 / 0.032$ & & $-4.711 / 0.000$ & & $-2.978 / 0.003$ & \\
\hline $\begin{array}{l}\text { 'Participation' } \\
\text { ( Factor 3) }\end{array}$ & $17.77 / 5.05$ & $18.86 / 3.79$ & $18.14 / 4.61$ & $23.43 / 4.86$ & $20.78 / 4.92$ & $16.47 / 3.84$ & $20.44 / 4.33$ & $17.27 / 4.63$ \\
\hline Z-/P-value & $-1.420 / 0.156$ & & $-2.634 / 0.006$ & & $-3.723 / 0.000$ & & $-2.889 / 0.004$ & \\
\hline $\begin{array}{l}\text { 'The profession' } \\
\text { (Factor 4) }\end{array}$ & $16.50 / 3.47$ & $18.14 / 3.29$ & $16.95 / 3.09$ & $20.71 / 2.98$ & $18.88 / 3.24$ & $15.81 / 3.12$ & $18.78 / 3.13$ & $16.34 / 3.40$ \\
\hline Z-/P-value & $-2.106 / 0.035$ & & $-2.671 / 0.006$ & & $-3.558 / 0.000$ & & $-2.616 / 0.009$ & \\
\hline $\begin{array}{l}\text { 'Meaningfulness' } \\
\text { (Factor 5) }\end{array}$ & $17.89 / 3.56$ & $19.90 / 3.70$ & $18.45 / 3.35$ & $22.71 / 2.50$ & $20.88 / 3.59$ & $17.01 / 2.93$ & $20.50 / 3.21$ & $17.76 / 3.60$ \\
\hline Z-/P-value & $-2.209 / 0.027$ & & $-2.883 / 0.003$ & & $-4.326 / 0.000$ & & $-2.843 / 0.004$ & \\
\hline $\begin{array}{l}\text { 'Study literature' } \\
\text { (Factor 6) }\end{array}$ & $17.87 / 5.14$ & $20.19 / 3.84$ & $18.24 / 4.83$ & $24.00 / 3.74$ & $21.83 / 3.94$ & $17.55 / 4.35$ & $20.83 / 3.98$ & $17.73 / 4.97$ \\
\hline Z-/P-value & $-2.048 / 0.041$ & & $-2.852 / 0.003$ & & $-4.660 / 0.000$ & & $-2.622 / 0.009$ & \\
\hline $\begin{array}{l}\text { 'Developing - } \\
\text { Resources' (Factor 7) }\end{array}$ & $17.86 / 3.06$ & $18.02 / 2.73$ & $18.08 / 2.95$ & $20.43 / 3.21$ & $19.17 / 3.24$ & $17.15 / 2.51$ & $18.91 / 2.73$ & $17.56 / 2.97$ \\
\hline Z-/P-value & $-0.326 / 0.744$ & & $-1.738 / 0.086$ & & $-2.664 / 0.008$ & & $-1.885 / 0.059$ & \\
\hline
\end{tabular}

Mann-Whitney U Test using asymptotic inference * Courses ground level

Total items (34-170); Factor 1 (2-10); Factor 2(5-20); Factor 3 (6-30); Factor 4(5-20); Factor 5 (5-25); Factor 6(6-30), Factor 7 (5-25)

Published by Sciedu Press 


\subsection{Research awareness and use of nursing research}

Seventy-four per cent ( $n=49$ of 66$)$ of the nurses reported that they never read any of the most common scientific journals presented. Sixty per cent ( $n=41$ of 68$)$ answered that they never or seldom used nursing research in their daily work. Forty-six percent ( $n=32$ of 70 ) answered that they knew about at least one Swedish researcher $(\mathrm{PhD})$ in nursing. About $10 \%(n=7$ of 73$)$ had attended one or more public defense of a doctoral thesis during the past five years. Comparing data related to the facilitators who had taken part in the network significantly more of them read common scientific journals presented in the questionnaire $\left(\chi^{2}=10.863, p=.003\right)$ and knew about Swedish researchers $\left(\chi^{2}=6.813, p=.014\right)$ than the staff nurses.

\subsection{I mpact of the network on and hindrances for development work}

Findings from the group interviews showed that development work had been initiated by the network in eight of the eleven wards. In one ward two development projects were initiated. The development projects had mainly been carried out by the facilitator with little collaboration with staff nurses in the wards. The following themes emerged from the analysis concerning hindering factors for development work based on research findings: 'lack of time for the nurses', 'lack of knowledge in EBP', 'language barriers', 'computer problems' 'lack of involvement of and interest from the head nurses' and 'lack of involvement of and interest from the nurses in the wards'. The findings from the questionnaires showed that according to $47 \%$ of the respondents ( 34 of 72 ) development work had been going on in the wards during the period when network support was provided. Less than half of them $(n=15$ of 34$)$, thought that this development work was initiated by the network.

\section{Discussion}

This was a follow-up study of a project aimed at improving the research utilisation in eleven wards by means of a network for support to nurses who were expected to take on a facilitator role for their colleagues. The findings showed that one and a half years after onset of the project development work had been initiated by the network only in eight of the eleven wards. The facilitators had mostly worked with these development projects by themselves without involving their colleagues as expected. As involvement is an important factor for a change of attitudes and interest among nurses in regard to research utilisation in nursing practice ${ }^{[28,29]}$, this finding is both disappointing and serious. The themes which evolved from the interview data showed that the hindering factors for development work were: "lack of time for the nurses', 'lack of knowledge in EBP', 'language barriers', 'computer problems' 'lack of involvement of and interest from the head nurses' and 'lack of involvement of and interest from the nurses in the wards'. These obstacles have already been reported many times ${ }^{[30-32]}$ of which the lack of interest and involvement of the nurse leader in the ward have been recurrently stressed. Since nurse leaders in clinical nursing are responsible not only for nursing quality, but also for time-scheduling and staffing, as well as for the professional development and learning environment for the nursing personnel ${ }^{[33,34]}$, they should have a key-role in the EBP process ${ }^{[35,36]}$. Therefore, when this project was initiated from the university, this group should have been more clearly invited to share the 'owner- role' together with the nurse lecturers.

The findings showed that most of the nurses had a positive attitude towards research in nursing, which is in line with recent studies ${ }^{[36-38]}$. However, when scrutinizing details in our findings and comparing these with an earlier Swedish study ${ }^{[23]}$ and a Spanish study ${ }^{[39]}$ where the same instrument was used, the nurses in the current study were less positive. This is discouraging since the network was expected to influence not only the facilitators but also their colleagues in the wards to use research findings in order to ensure evidence-based nursing. The facilitators had a generally more positive attitude to research compared to their colleagues. The reason for this could easily be explained as they were recruited to the network due to their interest in nursing development. The network intended to train and support them in the EBP process including such things as searching for and critical reviewing of scientific knowledge. However, findings from the interviews suggested that they needed more support and training in the EBP process than what was provided. It was notable that they did not report higher research use than the staff nurses. This may be understood in the light of the low academic education the facilitators had. According to Milner et al. ${ }^{[17]}$ the competence of a facilitator for EBP would be based on a degree in 
Nursing, which only a few of the facilitators in our study had. Most eligible for the facilitator role would be a level of Master's Degree, but as the lack of higher educated nurses in clinical nursing is quite conspicuous all over the world ${ }^{[40-41]}$, we consider that BSc degree could be good enough for starting with.

Nurses in our study were most positive to the factors 'Need of research knowledge', 'The profession', 'Meaningfulness', and 'Developing - Resources' than to the factors 'Research language', 'Study literature', and 'Participation'. This indicates that the nurses were aware of the need to use nursing research, and were positive to research for development of care. It was notable that factors that more deeply concerned them as persons scored lower than more general factors. This was found in e.g. 'complicated to understand the research language', 'have the interest for reading nursing science articles', and 'participate in development and research in nursing'. The findings also showed that about two-thirds of the nurses never read any of the most common scientific journals presented in the questionnaire, and more than half of them never or seldom used nursing research in their daily practices. This agrees with what has been reported both a decade ago and more recently ${ }^{[23,42-45]}$. According to Forsman, Rudman, Gustavsson, Ehrenberg \& Wallin ${ }^{[46]}$ the research use profile stays the same over time and low users tend to become even lower users. Hence the question still remains, how to get further in research utilisation so that individual nurses really are working in line with what they consider important.

When comparing nurses' attitudes to research with background variables our findings had a high congruence with what has been found in previous studies ${ }^{[23,47]}$, namely that education has a positive impact on nurses' attitudes to research utilisation. The nurses who had their nursing exam in 1996 or later showed significantly more positive attitudes towards nursing research, compared with nurses who had taken a nursing exam before 1996. They were more positive to the nursing profession as academically orientated, to meaningfulness of development in nursing and nursing research, and to studying literature. One reason could be that the Diploma nursing education in Sweden was transferred to an academic level (Bachelor degree) in $1993^{[48]}$ and the first group of nurses had their exam in 1996. Further, the nurses with a higher level of academic studies in nursing were also more positive to all factors except one 'Developing - Resources', than nurses with less academic studies. According to Mashiach Eizenberg ${ }^{[31]}$ academic education in nursing impacts positively on development of EBP as well.

Work-place seemed to influence nurses' attitudes since nurses working at the urban hospital were overall significantly more positive towards nursing research than those who worked at the rural hospitals. In addition, nurses who had previously participated in some nursing research/development work were significantly more positive to almost all factors than nurses without such experience. Most of these nurses were working at the urban hospital. One explanation for these findings could be that nurses in rural hospitals have fewer opportunities to be invited and take part in research projects due to the distance to the university ${ }^{[49]}$.

The findings in this study, as well as in others, highlight the importance of organisational support where nurse leaders take on the responsibility in evidence-based nursing practice ${ }^{[31,50]}$. Many clinical nurses have reported that such support is lacking ${ }^{[51]}$. As nurses' work environment is often busy and stressful, and implementing research findings as a routine in daily care takes time, it might be pure utopia to expect all clinical nurses in the wards to be involved in all the steps of the EBP process ${ }^{[52]}$. Even if it is a requirement of and an obligation for all professional nurses to work evidence-based, this does not automatically mean that they must do all the search-work, reading and analyzing of the research literature by themselves. This would better fit within the facilitator role. However, as professional nursing requires nurses who reflect upon their practices ${ }^{[53,54]}$, all nurses in the wards should be involved continuously throughout the EBP process e.g. in discussions in regularly-scheduled and compulsory ward meetings led by the nurse leader.

\section{Methodological consideration}

In this study there are some methodological aspects that should be addressed. As this was a follow-up study where data were collected one and a half years after onset of the network, some shortage in the registration of participants occurred. The head nurses asked the nurses in the wards about participation in the study, but the total number of nurses eligible was 
not recorded. From the beginning there were two facilitators in each of the eleven wards, but only eleven answered the questionnaire. One reason for this could be nurses' turnover ${ }^{[5]}$. The instrument which was used has been tested and judged as satisfactorily valid and reliable in earlier studies ${ }^{[23,47]}$. The quantitative part of study included 117 nurses, corresponding to a response rate of $64 \%$ which was fairly good ${ }^{[25]}$. However, due to the small size of some groups, it is not possible to draw any far-reaching conclusion from the comparison, but the findings are nevertheless worth noting. Group interviews were chosen to provide deeper understanding about the impact of the network on, and obstacles for research utilisation. The small, homogeneous groups which were used provided a safe and trustful environment for the interview, which improved the validity of data ${ }^{[56]}$. To enhance the trustworthiness of the findings the research team collaborated in the analysis until consensus was obtained. The combination of quantitative and qualitative data could further strengthen both the understanding of questions under study and its validity ${ }^{[26]}$.

\section{Conclusion and implication for clinical practice}

Providing network to facilitator nurses on the ward could be one way to improve research utilisation in nursing care. However, in order to reach the goals the network must be well anchored on the ward, and supported by the nurse leaders, so that all nurses can be involved in the process. Practical training in research use in the network is important. Further research on how network support can improve nurses' use of research in clinical practice is needed.

\section{References}

[1] Estabrooks, C.A. Will evidence-based nursing practice make practice perfect? Canadian Journal of Nursing Research. 1998; 30(1): 15-36.

[2] Estabrooks C.A. Translating research into practice: Implications for organisations and administrators. Canadian Journal of Nursing Research. 2003; 35(3): 53-68.

[3] Gerrish K. Evidence-based practice: unraveling the rhetoric and making it real. Practice Development in Health Care. 2003; 2: 99-113. http://dx.doi.org/10.1002/pdh.95

[4] Ciliska D. Evidence-based nursing: how far have we come? What's next? Evidence Based Nursing. 2006; 9: 38-40. http://dx.doi.org/10.1136/ebn.9.2.36

[5] Boström A-M., Wallin L. \& Nordström G. Evidence-based practice and determinants of research use in elderly care in Sweden. Journal of Evaluation in Clinical Practice. 2007; 13: 665-673. http://dx.doi.org/10.1111/j.1365-2753.2007.00807.x

[6] Parahoo K. \& McCaughan E.M. Research utilization among medical and surgical nurses: a comparison of their self-reports and perceptions of barriers and facilitators. Journal of Nursing Management. 2001; 9: 21-30. http://dx.doi.org/10.1111/j.1365-2834.2001.00237.x

[7] Sitzia J. Barriers to research utilisation: the clinical setting and nurses themselves. Intensive and Critical Care Nursing. 2002; 18: 230-243. http://dx.doi.org/10.1016/S0964339702000125

[8] Hutchinson A.M. \& Johnston L. Bridging the divide: a survey of nurses' opinions regarding barriers to, and facilitators of, research utilization in the practice setting. Journal of Clinical Nursing. 2004; 13: 304-315. http://dx.doi.org/10.1046/j.1365-2702.2003.00865.x

[9] Cummings G.G, Estabrooks C.A., Midodzi W.K., Wallin L. \& Hayduk L. Influence of organizational characteristics and context on research utilization. Nursing Research. 2007; 56(4): 24-39. http://dx.doi.org/10.1097/01.NNR.0000280629.63654.95

[10] Gerrish K., Ashworth P., Lacey A. \& Bailey J. Developing evidence-based practice: experiences of senior and junior clinical nurses. Journal of Advanced Nursing. 2008; 62(1): 62-73. http://dx.doi.org/10.1111/j.1365-2648.2007.04579.x

[11] Hannes K., Vandersmissen J., De Blaeser L., Peeters G., Goedhuys J. \& Aertgeerts A. Barriers to evidence-based nursing: a focus group study. Journal of Advanced Nursing. 2007; 60(2): 162-171. http://dx.doi.org/10.1111/j.1365-2648.2007.04389.x

[12] Andersson N., Cederfjäll C., Jylli L., Nilsson Kajermo K. \& Klang B. Professional roles and research utilization in paediatric care: newly graduated nurses' experiences. Scandinavian Journal of Caring Sciences. 2007; 21: 91 - 97. http://dx.doi.org/10.1111/j.1471-6712.2007.00435.x

[13] Veeramah V. Utilization of research findings by graduate nurses and midwives. Journal of Advanced Nursing. 2004; 47(2): 183-191. http://dx.doi.org/10.1111/j.1365-2648.2004.03077.x 
[14] Kitson A., Harvey G. \& McCormack B. Enabling the implementation of evidence-based practice: a conceptual framework. Quality in Health Care. 1998; 7(3): 149-158. http://dx.doi.org/10.1136/qshc.7.3.149

[15] Rycroft-Malone J. The PARIHS Framework - A Framework for Guiding the Implementation of Evidence-based Practice. Journal of Nursing Care Quality. 2004; 19(4): 297-304.

[16] McCormack B., Manley K., Kitson A., Kitchen A. \& Harvey G. Towards practice development - a vision in reality without vision? Journal of Nursing Management. 1999; 7: 255-264. http://dx.doi.org/10.1046/j.1365-2834.1999.00133.x

[17] Milner M.F., Estabrooks C.A. \& Humphrey C. Clinical nurse educators as agents for change: increasing research utilization. International Journal of Nursing Studies. 2005; 42: 899-914. http://dx.doi.org/10.1016/j.ijnurstu.2004.11.006

[18] Stone C. \& Rowles C.J. Nursing students can help support evidence-based practice on clinical nursing units. Journal of Nursing Management. 2007; 15: 367-370. http://dx.doi.org/10.1111/j.1365-2834.2007.00713.x

[19] Harvey, G., Loftus-Hills A., Rycroft-Malone J., Titchen A, Kitson A., McCormack B. et al. Getting evidence into practice: The role and function of facilitation. Journal of Advanced Nursing. 2002; 37: 577-588 http://dx.doi.org/10.1046/j.1365-2648.2002.02126.x

[20] Winch, S., Henderson, A. \& Creedy, D. 'Read, think, do!: a method for fitting research evidence into practice'. Journal of Advanced Nursing. 2005; 50(1): 20-26. http://dx.doi.org/10.1111/j.1365-2648.2004.03345.x

[21] Rosswurm M.A. \& Larrabee J.H. A model for change to evidence-based practice. Image - The Journal of Nursing Scolarship. 1999; 31 : 317-322. http://dx.doi.org/10.1111/j.1547-5069.1999.tb00510.x

[22] Leach M.J. Evidence-based practice: A framework for clinical practice and research design. International Journal of Nursing Practice. 2006; 12: 248-251. http://dx.doi.org/10.1111/j.1440-172X.2006.00587.x

[23] Björkström M.E, \& Hamrin E.K.F. Swedish nurses' attitudes towards research and development within nursing. Journal of Advanced Nursing. 2001; 34(5): 706-714. http://dx.doi.org/10.1046/j.1365-2648.2001.01800.x

[24] Hazard Munro B. Statistical methods for health care research. Lippincott Williams and Wilkins, Philadelphia; 2001.

[25] Polit D.F. \& Beck C.T. Essentials of Nursing Research: Appraising Evidence for Nursing Practice. Lippincott Williams \& Wilkins, Philadelphia; 2009.

[26] Lincoln Y.S. \& Guba E.G. Naturalistic inquiry. Beverly Hills, CA: Sage; 1995.

[27] Northern Nurses` Federation. Ethical guidelines for nursing research in the Nordic countries. Nordic Journal of Nursing Research and Clinical Studies. 2003; (Vård i Norden): 23 (4), supplement 1-5 (In Swedish).

[28] Henderson A., Winch S., Grugan C., Henney R. \& McCoy R. 'Working from the inside': an infrastructure for the continuing development of nurses' professional practice. Journal of Nursing Management. 2005; 13: 106-110. http://dx.doi.org/10.1111/j.1365-2934.2004.00497.x

[29] Henderson A. \& Winch S. Commentary. Managing the clinical setting for best nursing practice: a brief overview of contemporary initiatives. Journal of Nursing Management. 2008; 16: 92-95. http://dx.doi.org/10.1111/j.1365-2934.2007.00803.x

[30] Uysal A., Temel A.B., Ardahan M. \& Ozkahraman S. Barriers to research utilisation among nurses in Turkey. Journal of Clinical Nursing. 2010; 19: 3443-3452. http://dx.doi.org/10.1111/j.1365-2702.2010.03318.x

[31] Mashiach Eizenberg M. Implementation of evidence-based nursing practice: nurses' personal and professional factors. Journal of Advanced Nursing. 2011; 67(1): 33-42. http://dx.doi.org/10.1111/j.1365-2648.2010.05488.x

[32] Solomons N.M. \& Spross J.A. Evidence-based practice barriers and facilitators from a continuous quality improvement perspective: an integrative review. Journal of Nursing Management. 2011; 19: 109-120.

http://dx.doi.org/10.1111/j.1365-2834.2010.01144.x

[33] Failla K.R. \& Stichler J.F. Managers and staff perceptions of the manager's leadership style. Journal of Nursing Administration. 2008; 38(11): 480-487. http://dx.doi.org/10.1097/01.NNA.0000339472.19725.31.

[34] McCallin A.M. \& Frankson C. The role of the charge nurse manager: a descriptive exploratory study. Journal of Nursing Management. 2010; 18: 319-325. http://dx.doi.org/10.1111/j.1365-2834.2010.01067.x

[35] Johansson B., Fogelberg-Dahm M. \& Wadensten B. Evidence-based practice: the importance of education and leadership. Journal of Nursing Management. 2010; 18: 70-77. http://dx.doi.org/10.1111/j.1365-2834.2009.01060.x

[36] Wangensteen S., Johansson I.S., Björkström M. \& Nordström G. Research utilisation and critical thinking among graduate nurse: predictors for research use. A quantitative cross-sectional study. Journal of Clinical Nursing. 2011; 20: 2436-2447. http://dx.doi.org/10.1111/j.1365-2702.2010.03629.x

[37] Boström A-M., Nilsson Kajermo K., Nordström G. \& Wallin L. Registered nurses' use of research findings in the care of older people. Journal of Clinical Nursing. 2009; 18: 1430-1441. http://dx.doi.org/10.1111/j.1365-2702.2008.02370.x

[38] Witzke A.K., Bucher L., Collins M., Essex M., Prata J., Thomas T., Waterhouse J. \& Wintersgill W. Research needs assessment: Nurses' knowledge, attitudes, and practices related to research. Journal for Nurses in Staff Development. 2011; 24(1): 12-18. http://dx.doi.org/10.1097/01.NND.0000300846.89598.85 
[39] Moreno-Casbas T., Fuentelsaz-Gallego A., Gil de Miguel Á., González-María E. \& Clarke S.P. Spanish nurses’ attitudes towards research and perceived barriers and facilitators of research utilization: a comparative survey of nurses with and without experience as principle investigators. Journal of Clinical Nursing. 2011; 20: 1936-1947. http://dx.doi.org/10.1111/j.1365-2702.2010.03656.x

[40] Smith K.M. \& Crookes P.A. Re-thinking scholarship: Implications for the nursing academic workforce. Nurse Education Today. 2011; 31: 228-230. http://dx.doi.org/10.1016/j.nepr.2013.02.006

[41] Rollins Gantz N., Sherman DR., Jasper M., Choo C. G., Herrin-Griffith D. \& Harris K. Global nurse leader perspectives on health-systems and workforce challenges. Journal of Nursing Management. 2012; 20: 433-443. http://dx.doi.org/10.1111/j.1365-2834.2012.01393.x

[42] Parahoo, K. Research utilization and research related activities of nurse in Northern Ireland. International Journal of Nursing Studies. 1998; 35: 283-291. http://dx.doi.org/10.1016/S0020-7489(98)00041-8

[43] Wallin L., Boström A-M., Wikblad K. \& Ewald U. Sustainability in changing clinical promotes evidence-based nursing care. Journal of Advanced Nursing. 2003; 41(5): 509-518. http://dx.doi.org/10.1046/j.1365-2648.2003.02574.x

[44] Forsman H., Gustavsson P., Ehrenberg A., Rudman A. \& Wallin L. Research use in clinical practice - extent and patterns among nurses one and three years post-graduation. Journal of Advanced Nursing. 2009; 65(6): 1195-1206. http://dx.doi.org/10.1111/j.1365-2648.2008.04942.x

[45] Breimaier H.E., Halfens R.J.G. \& Lohrmann C. Nurses' wishes, knowledge, attitudes and perceived barriers on implementing research findings into practice among graduated nurses in Austria. Journal of Clinical Nursing. 2011; 20: 1744-1756. http://dx.doi.org/10.1111/j.1365-2702.2010.03491.x.

[46] Forsman H., Rudman, A., Gustavsson P., Ehrenberg A. \& Wallin L. Use of research by nurses during their first two years after graduating. Journal of Advanced Nursing. 2010; 66(4): 878-890. http://dx.doi.org/10.1111/j.1365-2648.2009.05223.x

[47] Björkström M.E., Johansson I.S., Hamrin E.K.F. \& Athlin E.E. Swedish nursing students' attitudes to and awareness of research and development within nursing. Journal of Advanced Nursing. 2003; 41(4): 393-402. http://dx.doi.org/10.1046/j.1365-2648.2003.02557.x

[48] Pilhammar Andersson E. From vocational training to academic education. The situation of the schools of nursing in Sweden. Journal of Nursing Education. 1999; 38: 33-38.

[49] Olade R.A. Evidence-based practice and research utilization activities among rural nurses. Clinical Scholarship. 2004; 36(3): 220-225. http://dx.doi.org/10.1111/j.1547-5069.2004.04041.x

[50] Gifford W., Davies B., Edwards N., Friffin P. \& Lybanon V. Managerial leadership for nurses' use of research evidence: An integrative review of the literature. Worldviews on Evidence-Based Nursing. 2007; Third Quarter, 126-145. http://dx.doi.org/10.1111/j.1741-6787.2007.00095.x

[51] Chummun H. \& Tiran D. Increasing research evidence in practice: a possible role for the consultant nurse. Journal of Nursing Management. 2008; 16: 327-333. http://dx.doi.org/10.1111/j.1365-2834.2007.00791.x

[52] Zeitz K. \& McCutcheon H. Evidence-based practice: To be or not to be, this is the question. International Journal of Nursing Practice. 2003; 9(5): 272-279. http://dx.doi.org/10.1046/j.1440-172X.2003.00440.x

[53] Benner P., Tanner C.A. \& Chesla C.A. Expertise in Nursing Practice: Caring, Clinical Judgment and Ethics. Springer, New York; 2009.

[54] Nelson S. The lost path to emancipatory practice: towards a history of reflective practice in nursing. Nursing Philosophy. 2012; 13: 202-213. http://dx.doi.org/10.1111/j.1466-769X.2011.00535.x

[55] Gardulf A., Söderström I-L., Orton M-L., Eriksson L.E., Arnetz B. \& Nordström G. Why do nurses at university hospital want to quit their jobs? Journal of Nursing Management. 2005; 13: 329-337. http://dx.doi.org/10.1111/j.1365-2934.2005.00537.x

[56] Morse J.M. ed. Critical Issues in Qualitative Research Methods. Sage Publications London, 1994. 